\title{
Rethinking the place of emotions in the field through social laboratories
}

\author{
Carolin Schurr ${ }^{\mathrm{a} *}$ and Katharina Abdo ${ }^{\mathrm{b}}$ \\ ${ }^{a}$ Department of Geography, University of Zurich, Winterthurerstrasse 190, Zurich 8057, \\ Switzerland; ${ }^{b}$ Department of Human Geography, Goethe University Frankfurt, Grüneburgplatz 1, \\ PEG-Gebäude, Frankfurt am Main 60323, Germany
}

(Received 17 October 2013; accepted 27 May 2014)

The insights of feminist science and technology studies (STS) into the constructed and situated nature of knowledge have proved crucial to informing feminist geography. Since the rise of emotional geographies, feminist methodologies no longer simply reflect on questions of positionality, partiality, and power relations, but also on the role of emotions in the field. In this article, we argue that a feminist STS perspective has much to offer when thinking about the way emotions are engineered, controlled, and negotiated in research processes. Our engagement with what we call 'social laboratories' - i.e., spaces in everyday life where (experimental) research is conducted with human beings - advances debates in feminist geography, as these laboratories crystallize the emotional entanglements feminists encounter in the field. Looking at economic experiments in Ghana and fertility clinics in Mexico, we discuss the difficulties of doing feminist fieldwork in these experimental research spaces. We argue that the constant negotiation of emotions and ethics is crucial to access, assess, and do fieldwork in research settings that do not adhere to feminist ideals, but nevertheless have gendered effects on women's and men's lives. Rethinking 'the place of emotions in research' (Bondi 2005, in Emotional Geographies, edited by Joyce Davidson, Liz Bondi, and Mick Smith, 231-246, Aldershot: Ashgate) through social laboratories forges instructive links across feminist/emotional geographies and social studies of science.

Keywords: feminist methodologies; fieldwork; emotions; laboratory studies; feminist science and technology studies

\section{Introduction}

A fictitious email exchange while conducting fieldwork:

Email Katharina: [...] Today I participated in a field experiment with farmers. From a STS point of view, it is really interesting to see how these kinds of experiments produce data about farmers' decision-making regarding people's purchasing of agricultural microinsurance. Observing economic experiments helps me to understand the role economics play in creating new microinsurance markets in the Global South. But at the same time, I feel quite uneasy to be part of this fairly positivist - and, at the same time, colonial - research setting. This laboratory, set up in small villages, works according to how the experimenter (a white $\mathrm{PhD}$ student from the Global North) runs the experiment, and there is little room for any kind of participative involvement by the 'subjects' (Ghanaian farmers).

Email Carolin: Similar struggles here! When I'm at a clinic, I'm really excited to learn so much about the fertility business. But it becomes very uncomfortable when I talk to surrogates or donors, and it becomes clear that they have received inaccurate or insufficient information

\footnotetext{
*Corresponding author. Email: carolin.schurr@geo.uzh.ch
} 
from the clinics about the procedures and the associated risks (!) - especially when someone from the agency or the clinic is around, listening in on the interview. When I tried to give more information to a donor yesterday (I was in her home), she said she'd rather not think about it too much ... It was clear that she really needs the money. Often, I really struggle to find my position in the maze of the fertility market here.

In this article, we rethink 'the place of emotions in research' (Bondi 2005; see also Widdowfield 2000) by engaging with the engineering of emotions in two social laboratories: economic experiments and fertility clinics. Emotions have gained increasing attention in feminist fieldwork thanks to the emotional turn. In doing so, emotional geographies are extending the call by feminist geographers for the embeddedness and partiality of knowledge (England 1994; Rose 1997) - which has resulted from insights from feminist science and technology studies (STS; Haraway 1988, 1991). Arguing that 'the field and the fieldworker are co-constructions, and the knowledge produced between them reflects the materiality and mutability of this relationship' (Katz 2009, 252), it has become feminist common sense that fieldwork is never an 'emotionless experience' (Spencer 1992, 59). Feminist geographers have shown how our struggles with our insider/outsider position in the field (Chattopadhyay 2012; Lobo 2010), our intersectional encounters in the field (Bondi 2005; Schurr and Segebart 2012; Valentine 2002), and moments of intimacy and friendship (Bondi 2003; Browne 2003; Cupples 2002) make fieldwork a truly emotional endeavor (see also the other articles in this special section).

Building upon, and simultaneously expanding, this body of literature, we call attention to a current blind spot in feminist methodologies: the emotional entanglements in which we find ourselves during fieldwork in social laboratories, and the ethical challenges that arise from these entanglements. We argue that in social laboratories, just like in the urban experiences Thrift $(2004)^{1}$ describes, emotions are affectively/effectively evoked, controlled, and disciplined to produce docile subjects for economic or biomedical laboratories. In short, emotions and behaviors are 'actively engineered' $(2004,58)$ in the spaces of social laboratories for the sake of knowledge production and capitalist marketmaking.

Not only do we analyze how experimental subjects' emotions are engineered, we also reflect on our own (powerful) emotional entanglements with these social laboratories. As Sharp et al. (2000, 24) have written, the term 'entanglement' conjures up 'the threadings, knottings and weavings of power' in which we as researchers are embedded, and which we actively (co)produce during our fieldwork. However, we employ the term not just in a metaphorical sense, but explore how relations of power are spun out and across the material spaces of social laboratories. Following Sharp et al., we argue that in such spaces of research assemblages of human subjects, scientific interventions, technologies, institutions, ideas, and emotions come together, circulate, convene, and reconvene, and 'it is only as a consequence of the spatial entangling together of all these elements that relations of power are established' $(2000,24)$. By focusing on our emotional entanglements with the manifold relations of power that constitute social laboratories, we aim to advance debates in feminist geography about the challenge of conducting 'ethical' research in settings where we as feminist researchers disagree with the very practices we study. We discuss how, in doing so, we struggle with (de)stabilizing the emotional logic of the field and the 'scientific' mode of knowledge production of the very social laboratories we aim to criticize in and through our research.

Our engagement with the engineering of emotions in laboratory settings informs larger questions about the systematic engineering of emotions in the research process. How are spaces of fieldwork brought into being through the constant control and management of 
emotions? How do we deal with our own and research subjects' emotions in the field? How do we negotiate ethics in research contexts that are - from a feminist point of view ethically problematic, such as social laboratories where experiments are performed with human beings? To what extent is our emotional entanglement simultaneously acceptable and problematic from a feminist point of view?

The article proceeds in the following manner. First, we review work in laboratory studies to show the lack of attention they pay to emotions, and we present social laboratories as new experimental sites that affectively/effectively bring everyday realities and markets into being. Second, we discuss our research design that is inspired by STS. We then show how emotions are engineered in the social laboratories we have studied, before discussing our emotional entanglements in, and with, these spaces. In the conclusion, we debate how our conceptualization of the field as a social laboratory advances feminist debates about ethical and emotional questions in fieldwork.

\section{Considering emotions in laboratory studies}

A fictitious email exchange while reading through STS literature:

Email Carolin: Thanks for the papers on laboratory studies. They really help me to think through how knowledge constantly needs to be stabilized and legitimized in fertility clinics. However, I sometimes find the accounts by the big STS guys really boring to read because of all the technical language. In the fertility clinics, however, the 'in vivo' experiments with new hormone drugs, new technical equipment and medical protocols have so much to do with emotions; the doctors are tense about possible side effects, the nurses are stressed out when performing a new, unknown protocol, and the donors feel uneasy when they are told to take another drug ....

Email Katharina: That's true! And I would go even further. Even though feminist STS scholars have written about the awkwardness and unease of being a social scientist doing research in a natural science lab (Roberts 2012; Thompson 2005), there has been little discussion about how we as feminist social scientists deal emotionally with what we observe in the laboratory.

Work in laboratory studies has inspired our own research, since this field has a long history of studying the processes of knowledge production in laboratory-like research settings. Laboratory studies focus on 'the in situ observation of scientific activity' (Woolgar 1982, 482) to get 'a better picture of what scientists do inside the walls of these strange places called "laboratories" (Latour 1983, 141). 'Studying what scientists actually do' (Pickering 1992, 2) and witnessing 'science in action' (Latour 1987), scholars of social studies of science have shown how scientific facts are produced and stabilized in the laboratory (Knorr-Cetina 1981; Lynch 1985). By demonstrating that universal claims of science are localized and contextual (Knorr-Cetina 1981) as well as embodied, situated, and partial (Haraway 1988), feminist STS have made major contributions to the social studies of science.

Recent work in this area has, however, pointed out some of the shortcomings of early laboratory studies. Garforth $(2012,265)$ argues that 'the centrality of the visual to epistemologies in [...] science and technology studies' has led to a tendency to count solely what can be seen. While she highlights the importance of invisible practices such as thinking, analyzing, and planning, in this article we bring to the foreground emotions as another invisible practice that fundamentally shapes knowledge production in social laboratories. In doing so, we follow feminist scholars' critique of the dominance of spectator epistemologies and visual modes of positivist knowledge (Braidotti 1991) and their attempt to reclaim vision as embodied and rooted in emotions (Haraway 1991, 188- 
190). In short, an embodied and felt mode of vision fruitfully complements and expands the focus of laboratory studies on visible practices, revealing another layer of practice that shapes knowledge production.

While laboratory studies' primary interest is in natural science laboratories, our research deals with a new kind of social laboratory where (experimental) research is conducted with human beings. Diverse disciplines such as development economics, biomedicine, behavioral, and consumer studies carry out experiments with human beings in everyday places such as clinics (Brännström et al. 2014; Silver 2014), schools (Miguel and Kremer 2004), or market squares (Banerjee and Duflo 2011; Besley 2012; Rodrik 2009). Social scientists have started to engage critically with these new spaces of research and have shown how such experiments blur the boundaries between the field and the lab (Teele 2014). This critical perspective reveals that these experimental spaces are not simply controlled laboratories in the field, but 'operative environments' (Petryna 2009, 30) that have performative effects on the lives and futures of the people involved. The existing literature on the experimentalization of life (Rheinberger 1997), real-world experiments (Kohler 2002), real-life experiments (Krohn and Weyer 1994), or experimentality (Nguyen 2009; Rottenburg 2009) focuses on new forms of governmentality and a 'novel figuration of science and politics' (Rottenburg 2009, 425) that result from the increasing use of experimental interventions. While we also observe this shift in governmental power in our case studies, in this article we look at one specific microtechnology of such a new mode of governmentality: the engineering of emotions in social laboratories. We argue in this article that we need to engage with these new forms of laboratories from a feminist perspective to understand how the feelings are systematically engineered in the name of science and markets.

\section{Researching market-making in social laboratories}

Both research projects are situated at the intersection of geographies of marketization and STS, and they are interested in how real markets are produced by bringing social realities in line with the laboratory conditions of biomedicine and economics. While the two social laboratories discussed in this article vary in scope and design, they both experiment with human beings to gather scientific data and improve market-making in the field of microinsurance and assisted reproduction (see Schurr and Fredrich 2015; Schurr and Walmsley 2014). Both projects employ an STS-inspired ethnographic approach (Knecht 2012): looking 'over the shoulders of the actors' (Geertz 1973) who run, work, and participate in the social laboratories, our ethnographic lens focuses on the micropractices of everyday research, experimentation, and market-making in these spaces. As the two projects study social laboratories located in postcolonial contexts in Ghana and Mexico, we have been particularly sensitive to their postcolonial modes of knowledge and market production (Anderson 2002). Employing a postcolonial STS lens, our research has looked at how racialized, classed, and gendered power relations played out in the social laboratories. Furthermore, work in feminist STS (Haraway 1988, 1996) has inspired our efforts to 'elucidate how gender relations figure in the construction of technology and science' (Wajcman 2000, 447) in social laboratories.

The economic experiment Katharina was studying is a classical field experiment that has become a fashionable method for development economists (Banerjee and Duflo 2011; Besley 2012; Rodrik 2009). Development economists set up experiments in rural villages to observe 'real people as they make real decisions in the real world' (Karlan and Appel 2011, 34). During her research on microinsurance markets in Ghana, Katharina 
accompanied a $\mathrm{PhD}$ student in development economics from a university in the Global North who was running various field experiments in cooperation with local institutions. The experiment investigated farmers' decision-making regarding the purchase of microinsurance products. The subjects - some 300 randomly assigned farmers in different villages - were asked to make hypothetical choices about purchasing fertilizer and/or various agricultural insurance options. Katharina's research aims to understand the role of economic experiments in bringing about new markets for microinsurance at the nexus of climate change adaptation and poverty reduction. To this end, she observed a number of different experimental settings such as an economic field experiment, simulation workshops, demonstrations of educational games, and experimental economics classes in Ghana and India as well as at various international conferences over the course of the last three years.

While the economic laboratory was temporally erected for the purpose of producing scientific data and, later, developing a financial product, at first glance the fertility clinics Carolin has studied correspond more to the traditional idea of biomedical laboratories rather than social laboratories. Fertility treatment is indeed closely related to biomedical laboratories, since in vitro fertilization (IVF) processes take place in these laboratories, along with the preparation and selection of eggs, sperms, and embryos. Although the Mexican fertility clinics run no controlled clinical trials (as described in Petryna 2009), clinicians, economists, and marketing experts experiment with human subjects and their emotions to improve their medical protocols, economic models, and marketing strategies. They often do so with no idea of the long-term effects of medical protocols, hormonal medication, and new forms of kinship on the intended parents, donors, and surrogates' lives. Looking at the fast-expanding market for transnational surrogacy in Mexico, the project seeks to understand how fertility clinics and related medical agencies turn people's most intimate desires for a child into a profitable business. Research was conducted at two fertility clinics in Cancún, three fertility clinics in Tabasco (the only state in Mexico where surrogacy is legal), five fertility clinics in Mexico DF, five donor/surrogate agencies that work simultaneously in different national and international spaces, and three international medical tourism agencies that put clients in touch with Mexican clinics. Fertility clinics in Mexico are generally private, upper-class, well-equipped, and nicely decorated medical practices in better-off parts of the city. While fertility clinics in Mexico DF predominantly provide services to Mexican middle- and upper-class patients, international patients are an important clientele for fertility centers in Tabasco and Cancún. During three months of fieldwork, STS-inspired ethnographic observation took place in the clinics, and interviews were conducted with a number of different actors.

It was the challenge of gaining and maintaining access to economic experiments and fertility clinics that triggered our discussion about the emotional entanglements we encounter when conducting research in social laboratories. Even though social laboratories transgress the confinements of classic laboratories, access is nevertheless controlled by the scientific authorities that run these spaces: it was up to the experimenter and the directing physician whether we were permitted to enter these spaces and observe the actions taking place. The sense of having both to please these authorities and being ourselves constantly under control while talking to research subjects resulted in our need to reflect on our emotional entanglements in these social laboratories and on the ethical challenges research in such settings implies. Before we do this, we shall show in the following section how the emotions of 'experimental subjects' are systematically engineered in social laboratories. 


\section{Engineering emotions in social laboratories}

'Creating a "laboratory" in the field can be a daunting task' (Viceisza 2012, 41). To create a lab-like setting in the field, participants (e.g., farmers, surrogates) need to be successfully recruited (through agencies), an environment needs to be installed where experimental subjects can be carefully controlled and turned into 'obedient' experimental subjects. Behaviors and emotions need to be affectively/effectively engineered in economic experiments and fertility clinics to make their business work.

Field note Katharina:

I was very excited when I met Mike $^{2}$ and he invited me to one of his field experiments. I sit next to the experimenter in front of the farmers. While three local assistants who are responsible for running the whole experiment are explaining the rules to the experimental subjects in their local language, Mike whispers the main rules of the game in my ear.

Especially at the beginning of the experiment, farmers quite frequently disrupt the explanations. They challenge the reality of the introduced situations or make long-winded comments about the problems on their farms. I feel Mike getting annoyed; from his point of view these 'interruptions' merely prolong an already long experiment and threaten the comparability of the sessions. In a long debate during a lunch break, he discusses this problem with the assistants and tells them: 'Next time you have to restrict them'. Besides giving instructions and restricting unwanted questions, the assistants also have to jolly the subjects along until the end of the experiment, which takes up to four hours. Throughout the session the assistants divert complaints and concerns, deal with objections by subtly circumventing them, wake up subjects who doze off, and convince impatient ones to stay until the end. In a smooth experiment, experimental subjects need to be awake, attentive, and obedient (field note November 2012).
Field note Carolin:

When Leo (director of the surrogate agency 'New Baby') asked me if I want to come to the inaugural session of his new foundation for surrogate mothers, I was quite happy to accept the invitation. Such an event would give me the opportunity to learn more about the emergence of new actors in the surrogate market in Mexico.

I am sitting here with six members of the foundation, listening to Leo who explains extensively the aims of the foundation.

He really seems to care about 'his' surrogates and his excitement and enthusiasm spills over. While I am still struggling with what I should think about his idea of opening a foundation for surrogates, I suddenly hear Leo say: 'I wouldn't have any secure rights over the women if we didn't have the foundation. I need to know where they go, with whom they spend their day, what they do during the day, if there is an accident, if they have sexual relations, if they feel well or have problems with the hormones, if they are depressed because of their kids. I can't go to their homes or install a camera under their beds. It is a lot easier if they spend their day in the foundation. You are going to be their psychologist of the everyday, you have to make sure that they feel well, take their medicine, obey the rules, and don't get too attached to the baby. It is a very delicate business, everything has to be controlled, if not, we won't have any successful pregnancies' (field note January 2014).

As the above field notes illustrate, both social laboratories aim to create a controlled environment in which personal emotions are contained. While in the economic experiments boredom, unease, or ill-humor need to be disciplined to ensure the experiment runs seamlessly, surrogates' sexual behavior, emotional attachment to their babies, and commitment to taking the medicine in the prescribed way need to be kept under constant surveillance to guarantee positive outcomes of the in vitro-induced pregnancies. Good success rates are crucial if the Mexican fertility clinics are to compete successfully in the 
transnational surrogacy market. Surveillance and control are exercised in both social laboratories by the white(ned) male scientists leading the economic experiment and the fertility clinic and their local assistants who make sure that the experimental subjects obey their orders.

The spatial arrangement of the experimental settings further helps to steer the experimental subjects' behavior and emotions. In the economic experiment, chairs are carefully arranged in the room to 'separate subjects from each other as much as possible' (Viceisza 2012, 43). However, this measure is not sufficient. Each time the subjects are to take a decision, things get messy and noisy: subjects ask their neighbors for help, others whisper and consult each other. The experimenter becomes quite annoyed and indignant and instructs the assistants to 'divide subjects between the three of you and control them.' The surrogate agency creates a particular space - the foundation building - where the surrogates can spend their days during the pregnancy. Under the altruistic pretext that the surrogates receive training at the foundation, the agency gains constant control over the surrogates, their emotions, behaviors, nutrition, and health by obliging them to participate in courses if they want to receive the full amount of money for their surrogate services. The 'psychologists of the everyday' - the people working in the foundation - make sure that the surrogates do not break out of the 'comfort zone' of the surrogate house. The control and surveillance, however, are never total, as the farmers and women who are supposed to be disciplined have agency to resist, contest, and subvert the rules of the social laboratories. Despite the greatest efforts, the farmers keep on talking to each other, women undergoing IVF question doctors when medical routines are changed, and the surrogate mothers decide for themselves if and when they have sexual relations.

\section{Emotional entanglements and ethical challenges in social laboratories}

So far, we have observed what is happening in the social laboratories in a traditional STS manner. Our silent observation helped us to understand how emotions are affectively/ effectively engineered for the sake of producing good economic data and pregnancy rates. Yet, as feminist STS scholars have shown, as researchers we are never just silent observers who see 'everything from nowhere' (Haraway 1988, 581); our vision is always embodied and situated. In the following, we discuss how we struggled through the emotional entanglements and ethical challenges with the power-laden logics of the social laboratories in the course of our research.

As the two field notes highlight, it did not take long until we became emotionally invested in the social laboratories. Of course, doing fieldwork always means becoming entangled - with our research topic, a certain place, and the people we encounter in our research. As feminist geographers have shown, these entanglements can be complex, messy, and puzzling (Browne 2003; Cupples 2002). Research ethics (Sultana 2007) and power relations (Chattopadhyay 2012; Datta 2008) in the field are important topics, which feminist geographers have addressed with regard to their positionality in the field. Rose $(1997,319)$ points to the fact that, when doing research, we 'inscribe into our research practices some absences and fallibilities.' Heeding her call, in the following section we discuss the 'anxieties and ambivalences that surround positionality and reflexivity' (1997, 306) in the field. We critically reflect on our 'absences and fallibilities' regarding our entanglements with (1) the authorities in social laboratories, (2) the 'experimental' subjects, and (3) feminist research ethics. 
Field note Katharina:

The experimenter decided to take a day off and asked me to replace him, remarking: 'It's probably interesting for you'. I agreed quite reluctantly. As I was grateful to him for having given me the chance to participate in the experiments without a lot of fuss, I felt obliged to support him. As I was quite skeptical about the experimental method, I was not best pleased when I suddenly became responsible for the experiment for one day. I was meant to keep the minutes of the procedure, noting extraordinary interventions or interruptions 'anything that affects the experiment, like people laughing too much', as the experimenter put it. While the assistants were explaining and running the experiment, I was struggling with my new role. Sweat was pouring down my neck; many thoughts and emotions were swirling around in my head. There were moments in which I had to force myself to put on a serious expression. I was so tense that I felt the urge to burst out laughing aloud, seeing everything in front of me as a bizarre theater. I felt embarrassed and ashamed of the colonial setting: me as a white academic in front of the 'experimental black subjects'; the assistants who were managing everything and whom I was supposed to supervise (field note November 2012).
Field note Carolin:

I feel exhausted, my body aches, my head is spinning. It was a long and confusing day. In the morning, I had an interview with Dr. Juan, the director of the biggest fertility clinic here. I somehow quite enjoyed the interview, Juan was relaxed and seemed interested in the research. We laughed a lot when he talked about the difficulties he had had constructing a fertility clinic here in the Caribbean, and his years of training in Spain. He told me that he does not do surrogacy, as it is such a sensitive ethical topic in Mexico.

Later that day, I received an email from Robert, a client of Dr. Juan's - he had just been ripped off by an international surrogate agency working with Dr. Juan's clinic. They had paid the money for the surrogate and the medical process, but the agency run away with the money, leaving the clinic without payment and Robert and his partner without a baby. $\mathrm{He}$ had found my email on a forum and was now asking for help to connect me with other people who had became victims of the fraud. Now, in the evening, I feel totally lost. It seems so difficult to know whom to trust, who speaks 'the truth', how to navigate between the different actors playing (not always necessarily with their cards on the table) a role in the maze of the fertility market (field note January 2014).

First, we both struggled to negotiate our relationship with the (male) authorities that facilitated our access to the social laboratories. Even though we are critical about what is going on in the economic experiments and fertility clinics, we developed some kind of personal relationship with them; we talked to them, laughed together, discussed our opinions, and shared an academic subject position in a context where such a position engenders closeness. Afraid of appearing ungrateful to them, we were reluctant to openly articulate our criticism of the experimental method used in the economic experiment or the way donors and surrogates are treated in the fertility clinic. After these encounters, we both often felt uneasy, since, by not articulating our criticism, we became complicit in the positivist and exploitive logic of the social laboratories. Feeling indebted to the experimenter/physician, in these moments of silence we reproduced these systems, even though our research aims to criticize the experimental mode of social laboratories in the long run. While we acknowledge that our silences are problematic from a feminist point of view, we argue that we can only critically evaluate the effects of these new social laboratories on women's and men's lives when we have access to them, when we spend time there and engage with the logic that dominate these social laboratories. So our silences can be considered strategic and pragmatic - though that does not make them any less problematic.

Second, our relationship with the 'authorities' complicated our emotional relationships with the 'experimental subjects.' Our being introduced to the experimental subjects, the surrogates, and donors by the male authorities often made us feel that they (nonsurprisingly) automatically positioned us on the side of the powerful, the whites. 
In short, our white bodies were positioned in a gendered, postcolonial power/knowledge landscape (McClintock 1995) that felt very uncomfortable, given our training in feminist and postcolonial studies. In the social laboratories, we both felt how not only the emotions and behaviors of the experimental subjects but also our own were affectively/ effectively engineered, leaving little room for maneuver for resistance and critical engagement. Katharina, for example, obeyed the rules of the experiment, even though she felt reluctant and ashamed of the postcolonial setting. But the space of the social laboratory assigned her this role and she performed it, as she felt indebted to the experimenter. Carolin often felt desperate when talking to donors or surrogates within the spaces of the clinics or agencies, as she could sense that the interviewees felt afraid of being eavesdropped on and of saying anything 'wrong' during the interview. In conversations that she managed to arrange outside the spaces of the fertility clinics and agencies, egg donors and surrogates spoke more openly about the limited options for earning a living in these parts of Mexico. The clinics' altruistic rhetoric about the joy of motherhood and the gift of fulfilling another person's biggest desire successfully infiltrated not only the discourses of donors and surrogates but also her own thinking. Is it not too easy to say that the clinics exploit the surrogates and donors? What about their agency and their choice? What risks would they face when working as empleadas in private households or staying with violent husbands?

Third, since we carried out these research projects, we have talked a lot about research ethics and whether one can and should do research in this kind of setting. Obviously, there is no easy answer to this question. What we know for sure is that research and reality is shaped through a fast-growing number of social laboratories. Leaving the development of what is happening in these spaces purely to economists, physicians, and pharmacists would mean missing chances of critically engaging with and transforming these new modes of knowledge production and market production. Our (often necessarily silent and not too critical) participation in these spaces is a crucial first step toward understanding the logic and functioning of social laboratories. We are aware, however, that participating silently in these spaces is not sufficient. As a second step, we need to think collectively how we can critically engage with the modes of social laboratories from a feminist perspective. How can we open up discussions about research methods, ethics, and power relations in social laboratories? How can our research in social laboratories reveal the limitations of experimental research settings and the risks for experimental human subjects? While we acknowledge that our positions in the social laboratories differ significantly from those of experimental subjects, we argue that 'feeling' through our own bodies the modes of affective engineering that constitute social laboratories is a crucial first step toward understanding how social laboratories work. This article serves as a second step in a process of critical reflection about the ethical dilemmas of affective engineering in social laboratories. We hope that it sparks discussion about how to engage and confront such experimental spaces.

\section{Conclusions}

In this article we have discussed the challenges and difficulties of conducting research as feminists in social labs. To conclude, we would like to reflect on how the blurring of the boundaries between the field and the lab and our emotional entanglements with and in the social laboratories inform current feminist debates about ethics and emotions in the field. 
First, the empirical case studies of the field experiment and the fertility clinics show how the boundaries between the field and the lab are becoming increasingly blurred. New technological and medical developments in biomedicine, and the growing popularity of running field experiments in economics have turned spaces of everyday life into social laboratories. At the same time, scholars in STS treat the laboratory as their 'field sites,' studying the researchers and lab assistants like the tribes or communities that ethnographers have traditionally observed. While STS interventions in (natural science) laboratories have revealed the constructed nature of all knowledge production, our engagement with social laboratories highlights how we, as feminist researchers, can become implicated in a positivist logic. Following Bennett $(2002,143)$, who states that 'there is nothing natural about the field,' we argue that any kind of fieldwork takes place in laboratory-like, staged spaces of knowledge production. Given the blurred boundary between the field and the lab, we call for researchers to acknowledge the performative character of fieldwork, to question how our own and our research participants' emotions are (un)consciously engineered in the course, and as an affect/effect, of research, and to think carefully about our multiple and powerful entanglements in the field.

Second, our article has shown how we struggled through the ethical and emotional challenges we encountered while conducting research in experimental spaces, despite years of training and the knowledge produced by decades of feminist methodologies in the social sciences. Even though we were reluctant about it, as feminist researchers we have become implicated in the (positivist and postcolonial) logic of the laboratories we studied. Our engagement as feminists in these scenarios required a certain kind of emotional complicity from both of us. Although we found it very challenging to negotiate our emotional entanglements in the field, we do not think that we should abandon these research areas altogether. Rather, we suggest we should be more explicit about our emotional entanglements in the field. We have to adapt to a certain degree to the emotional regime of the space we study in order to gain and maintain access to these spaces, and learn more about the gendered implications that the research undertaken in the laboratories has on women and men's everyday lives. Negotiating and struggling through our emotional entanglements is an important step toward coping with our paradoxical position as both insiders and outsiders of the laboratory. Critical reflection on the emotional entanglements we encounter in the field enables feminist researchers simultaneously to understand the hegemonic emotional regimes of experimental research and think about modes of challenging these regimes through our engagement with these spaces.

\section{Acknowledgments}

We thank Nicole Laliberté, Heidi Kaspar, and Martin Müller for their caring support, insightful reflections, and intellectual suggestions from which we immensely benefited in the writing and revision process of this paper. The editor Pamela Moss and the anonymous reviewers involved have played a crucial role in improving the argument of the paper. We are very grateful for their encouragement to think about more creative and emotional ways of presenting our work. Finally, we thank the research participants who made our research in the social laboratories in Ghana and Mexico possible.

\section{Funding}

The research was financed by the generous support of the Branco Weiss Fellowship and the Deutsche Forschungsgemeinschaft. 


\section{Notes}

1. While employing Thrift's notion of 'engineering,' we do not engage in the dispute between feminist geographies of emotions and more-than-representational geographies of affect in this article. Following Ahmed (2004), we think that such a distinction between precognitive affect and conscious emotions is not very fruitful; we consider emotion and affect to be inseparable from each other.

2. The names of people, institutions, and places have been anonymized.

\section{Notes on contributors}

Carolin Schurr is a Branco Weiss Fellow in the Department of Geography at the University of Zürich, Switzerland. Her work focuses on the expansion of markets of assisted reproduction in the Global South.

Katharina Abdo is a PhD student and lecturer in the Department of Human Geography at the Goethe University of Frankfurt. Her research examines how new markets of agricultural microinsurance emerge at the nexus of climate change adaptation and poverty reduction.

\section{References}

Ahmed, Sara. 2004. The Cultural Politics of Emotion. Edinburgh: Edinburgh University Press.

Anderson, Warwick. 2002. "Introduction: Postcolonial Technoscience." Social Studies of Science 32 (5-6): 643-658.

Banerjee, Abhijit V., and Esther Duflo. 2011. Poor Economics: A Radical Rethinking of the Way to Fight Global Poverty. New York: PublicAffairs.

Bennett, Katy. 2002. "Participant Observation." In Doing Cultural Geography, edited by Pamela Shurmer-Smith, 139-144. London: Sage.

Besley, Timothy. 2012. "Review Essay: Poor Choices - Poverty from the Ground Level." Foreign Affairs, 160-167.

Bondi, Liz. 2003. "Empathy and Identification: Conceptual Resources for Feminist Fieldwork." ACME: International Journal of Critical Geography 2 (1): 64-76.

Bondi, Liz. 2005. "The Place of Emotions in Research: From Partitioning Emotion and Reason to the Emotional Dynamics of Research Relationships." In Emotional Geographies, edited by Joyce Davidson, Liz Bondi, and Mick Smith, 231-246. Aldershot: Ashgate.

Braidotti, Rosi. 1991. "Body-Images and the Pornography of Representation." Journal of Gender Studies 1: 137-151.

Brännström, Mats, Liza Johannesson, Pernilla Dahm-Kähler, Anders Enskog, Johan Mölne, Niclas Kvarnström, Cesar Diaz-Garcia, et al. 2014. "First Clinical Uterus Transplantation Trial: A Six-Month Report." Fertility and Sterility 101 (5): 1228-1236.

Browne, Kath. 2003. "Negotiations and Fieldworkings: Friendship and Feminist Research." ACME: An International E-Journal for Critical Geographers 2 (1): 132-146.

Chattopadhyay, Sutapa. 2012. "Getting Personal while Narrating the 'Field': A Researcher's Journey to the Villages of the Narmada Valley." Gender, Place \& Culture: A Journal of Feminist Geography 20 (2): 137-159.

Cupples, Julie. 2002. "The Field as a Landscape of Desire: Sex and Sexuality in Geographical Fieldwork." Area 34 (4): 382-390.

Datta, Ayona. 2008. "Spatialising Performance: Masculinities and Femininities in a 'Fragmented' Field." Gender, Place \& Culture: A Journal of Feminist Geography 15 (2): 189-204.

England, Kim. 1994. "Getting Personal: Reflexivity, Positionality, and Feminist Research." The Professional Geographer 46 (1): 80-89.

Garforth, Lisa. 2012. "In/Visibilities of Research: Seeing and Knowing in STS." Science, Technology \& Human Values 37 (2): 264-285.

Geertz, Clifford. 1973. The Interpretation of Cultures. New York: Basic Books.

Haraway, Donna. 1988. "Situated Knowledges: The Science Question in Feminism and the Privilege of Partial Perspective." Feminist Studies 14 (3): 575-599.

Haraway, Donna. 1991. Simians, Cyborgs, and Women: The Reinvention of Nature. London: Free Association Books. 
Haraway, Donna. 1996. "Modest Witness: Feminist Diffractions of Science Studies." In The Disunity of Science: Boundaries, Contexts, and Power, edited by Peter Galison and David J. Stump, 428-442. Stanford, CA: Stanford University Press.

Karlan, Dean S., and Jacob Appel. 2011. More than Good Intentions: How a New Economics Is Helping to Solve Global Poverty. New York: Dutton.

Katz, Cindi. 2009. "Fieldwork." In The Dictionary of Human Geography, edited by Derek Gregory, R. J. Johnston, Geraldine Pratt, Michael Watts, and Sarah Whatmore, 251-252. Oxford: WileyBlackwell.

Knecht, Michi. 2012. "Ethnographische Praxis Im Feld Der Wissenschafts-, Medizin- Und Technikanthropologie." In Science and Technology Studies: Eine Sozialanthropologische Einführung, edited by Stefan Beck, Jörg Niewöhner, and Estrid Sörensen, 245-274. Bielefeld: Transcript.

Knorr-Cetina, Karin. 1981. The Manufacture of Knowledge: An Essay on the Constructivist and Contextual Nature of Science. Oxford: Pergamon Press.

Kohler, Robert E. 2002. Landscapes \& Labscapes: Exploring the Lab-Field Border in Biology. Chicago, IL: University of Chicago Press.

Krohn, Wolfgang, and Johannes Weyer. 1994. "Real-Life Experiments. Society as a Laboratory: The Social Risks of Experimental Research." Science and Public Policy 21 (3): 173-183.

Latour, Bruno. 1983. “'Give Me a Laboratory and I Will Raise the World'.” In Science Observed: Perspectives on the Social Study of Science, edited by Karin Cetina and Michael Mulkay, 141-170. London: Sage.

Latour, Bruno. 1987. Science in Action. How to Follow Scientists and Engineers through Society. Cambridge, MA: Harvard University Press.

Lobo, Michele. 2010. "Negotiating Emotions, Rethinking Otherness in Suburban Melbourne." Gender, Place \& Culture: A Journal of Feminist Geography 17 (1): 99-114.

Lynch, Michael. 1985. Art and Artifact in Laboratory Science: A Study of Shop Work and Shop Talk in a Research Laboratory, Studies in Ethnomethodology. London: Routledge \& Paul.

McClintock, Anne. 1995. Imperial Leather: Race, Gender and Sexuality in the Colonial Contest. New York: Routledge.

Miguel, Edward, and Michael Kremer. 2004. "Worms: Identifying Impacts on Education and Health in the Presence of Treatment Externalities." Econometrica 72 (1): 159-217.

Nguyen, Vin-Kim. 2009. "Government-by-Exception: Enrollment and Experimentality in Mass HIV Treatment Programmes in Africa." Social Theory \& Health 7 (3): 196-217.

Petryna, Adriana. 2009. When Experiments Travel: Clinical Trials and the Global Search for Human Subjects. Princeton, NJ: Princeton University Press.

Pickering, Andrew. 1992. "From Science as Knowledge to Science as Practice.” In Science as Practice and Culture, edited by Andrew Pickering, 1-28. Chicago, IL: Chicago University Press.

Rheinberger, Hans-Jörg. 1997. Toward a History of Epistemic Things: Synthesizing Proteins in the Test Tube, Writing Science. Stanford, CA: Stanford University Press.

Roberts, Elizabeth F. 2012. God's Laboratory. Assisted Reproduction in the Andes. Berkeley, CA: University of California Press.

Rodrik, Dani. 2009. "The New Development Economics: We Shall Experiment, but How Shall We Learn?" In What Works in Development? edited by Jessica Lee Cohen and William Easterly, 24-47. Washington, DC: Brookings Institution Press.

Rose, Gillian. 1997. "Situating Knowledges: Positionality, Reflexivities and Other Tactics." Progress in Human Geography 21 (3): 305-320.

Rottenburg, Richard. 2009. "Social and Public Experiments and New Figurations of Science and Politics in Postcolonial Africa." Postcolonial Studies 12 (4): 423-440.

Schurr, Carolin, and Bettina Fredrich. 2015. "Serving the Transnational Surrogacy Market as a Development Strategy?" In A Handbook of Gender and Development, edited by Anne Coles, Leslie Grey, and Janet Momsen. London: Routledge.

Schurr, Carolin, and Dörte Segebart. 2012. "Tackling Feminist Postcolonial Critique through Participatory and Intersectional Approaches." Geographica Helvetica 67 (3): 147-154.

Schurr, Carolin, and Heather Walmsley. 2014. "Reproductive Tourism Booms on Mexico's Mayan Riviera.” International Medical Travel Journal (May 2014). http://www.imtj.com/articles/2014/ reproductive-tourism-booms-on-mexicos-mayan-riviera-40194/

Sharp, Joanne, Paul Routledge, Chris Philo, and Ronan Paddison. 2000. Entanglements of Power: Geographies of Domination/Resistance. London: Routledge. 
Silver, Robert. 2014. "Infertility Trial Outcomes: Healthy Moms and Babies." Fertility and Sterility 101 (5): $1209-1216$.

Spencer, Paul. 1992. "Automythologies and the Reconstruction of Ageing." In Anthropology and Autobiography, edited by Judith Okely, and Helen Callaway, 50-62. London: Routledge.

Sultana, Farhana. 2007. "Reflexivity, Positionality and Participatory Ethics: Negotiating Fieldwork Dilemmas in International Research." ACME: An International E-Journal for Critical Geographers 6 (3): 374-385.

Teele, Dawn Langan. 2014. Field Experiments and Their Critics. New Haven, CT: Yale University Press.

Thompson, Charis. 2005. Making Parents: The Ontological Choreography of Reproductive Technologies. Cambridge, MA: MIT Press.

Thrift, Nigel. 2004. "Intensities of Feeling: Towards a Spatial Politics of Affect." Geografiska Annaler 86 (1): 57-78.

Valentine, Gill. 2002. "People Like Us: Negotiating Sameness and Difference in the Research Process." In Feminist Geography in Practice: Research and Methods, edited by Pamela Moss, 116-126. Oxford: Blackwell.

Viceisza, Angelino. 2012. Treating the Field as a Lab: A Basic Guide to Conducting Economics Experiments for Policymaking, Food Security in Practice. Washington, DC: International Food Policy Research Institute.

Wajcman, Judy. 2000. "Reflections on Gender and Technology Studies: In What State is the Art?" Social Studies of Science 30 (3): 447-464.

Widdowfield, Rebekah. 2000. "The Place of Emotions in Academic Research." Area 32 (2): $199-208$.

Woolgar, Steve. 1982. "Laboratory Studies: A Comment on the State of the Art." Social Studies of Science 12 (4): 481-498.

\section{ABSTRACT TRANSLATIONS \\ Repensando el lugar de las emociones en el trabajo de campo a través de laboratorios sociales}

Las miradas de los estudios de ciencia y tecnología (ECT) feministas en la naturaleza construida y situada del conocimiento han demostrado ser cruciales para la geografía feminista. Desde que surgieron las geografías emocionales, las metodologías feministas ya no reflexionan simplemente sobre cuestiones de posicionalidad, parcialidad y relaciones de poder sino también sobre el rol de las emociones en el trabajo de campo. En este artículo, sostenemos que una perspectiva de ECT feminista tiene mucho que ofrecer cuando pensamos acerca de la manera en que las emociones son creadas, controladas, y negociadas en los procesos de investigación. Nuestra participación en lo que llamamos 'laboratorios sociales' - esto es, espacios en la vida cotidiana donde la investigación (experimental) es conducida con seres humanos - avanza debates en la geografía feminista, ya que estos laboratorios cristalizan los entrelazamientos emocionales que las y los feministas encuentran en el campo. Analizando los experimentos económicos en Ghana y clínicas de fertilidad en México, discutimos las dificultades de llevar a cabo trabajo de campo feminista en estos espacios de investigación experimental. Sostenemos que esta negociación constante de las emociones y la ética es crucial para acceder, evaluar y llevar a cabo el trabajo de campo en los ambientes de investigación que no adhieren a los ideales feministas, pero que tienen, sin embargo, efectos generizados sobre las vidas de mujeres y hombres. Repensando 'el lugar de las emociones en la investigación' (Bondi 2005 ) a través de los laboratorios sociales forja lazos instructivos a través de las geografías feministas/emocionales y los estudios sociales de la ciencia.

Palabras claves: metodologías feministas; trabajo de campo; emociones; estudios de laboratorio; estudios de ciencia y tecnología feminista 


\section{透过社会实验室，再思考田野中的情绪地方}

女性主义科学与科技研究 (STS) 对于知识的建构和情境化本质之洞见, 已証实为 提供女性主义地理学信息的关键。随着情绪地理学的兴起, 女性主义方法论不再 仅止于反思位置性、偏倚与权力关係等问题, 更对情绪在田野中的角色进行反 思。我们于本文中主张, 女性主义STS的视角, 对于思考情绪在研究过程中被打 造、控制与协商的方式，有诸多的贡献。我们对于所谓的“社会实验室”的参与 - 例 如与人类进行 (实验性) 研究的每日生活空( \#x95F4; - 促进了女性主义地理学中的 辩论，因为这些实验室具体化了女性主义者在田野中遭遇的情绪纠结。我们检视 迦纳的经济实验, 以及墨西哥的生育诊所, 探讨在这些实验性的研究空间中从事 女性主义田野工作的困难。我们主张，不断地进行情绪与道德的协商，是在研究 环境中获得、评估以及从事田野工作的关键，虽然该过程不符合女性主义的理 想，但仍然对女性及男性的生活有着性别化的效应。透过社会实验室，再思 (\#x8003; '研究中的情绪地方' (Bondi 2005), 为女性主义/情绪地理学和科学社会 学之间，打造了具有啓发性的连结。

关键词：女性主义方法论; 田野工作; 情绪; 实验室研究; 女性主义科学与科技研究 